\title{
Analisis Perbandingan Ketelitian Model 3D Menggunakan Lensa Normal dan Lensa Fisheye
}

\section{(Comparative Analysis of Three-Dimensional (3D) Model Accuracy Generated from Normal Lens and Fisheye Lens)}

\section{Adi Nurcahyo' ${ }^{1}$, Djurdjani²}

1 Mahasiswa, Departemen Teknik Geodesi, Universitas Gadjah Mada, Indonesia

2 Dosen, Departemen Teknik Geodesi, Universitas Gadjah Mada, Indonesia

Penulis Korespondensi: Djurdjani | Email: djurdjani@ugm.ac.id

\begin{abstract}
ABSTRAK
Dalam pemodelan 3D, salah satu metode yang umum digunakan adalah close range photogrammetry (CRP). Pada umumnya, metode CRP menggunakan lensa normal yang memiliki distorsi lensa relative kecil. Lensa fisheye memiliki sudut pandang yang lebih besar dibandingkan lensa normal sehingga dapat mengurangi jumlah foto, namun memiliki distorsi yang besar sehingga dapat mempengaruhi ketelitian model 3D yang dihasilkan. Penelitian ini bertujuan untuk melakukan pengujian ketelitian geometrik antara lensa normal dan lensa fisheye. Penelitian dilakukan di Kawasan Candi Ratu Boko karena mudah diakses dan permukaan candi memiliki struktur yang detil. Data yang digunakan adalah foto objek candi, 10 titik GCP dan 10 titik ICP. Hasil model 3D lensa normal dan lensa fisheye sudah dapat memvisualisasikan objek dengan baik dari tingkat kedetilan dari struktur yang dihasilkan. Uji geometrik dilakukan dengan membandingkan jarak pada kedua model dengan jarak di lapangan serta ukuran ICP pada kedua model dengan ukuran ICP hasil akuisisi menggunakan total station reflectorless. Kedua uji tersebut menggunakan uji-t dengan tingkat kepercayaan 95\%. Hasil uji menunjukkan bahwa bahwa ketelitian model 3D lensa fisheye sama dengan ketelitian model 3D lensa normal. Lensa fisheye dapat menggantikan lensa normal untuk pemodelan 3D dalam kondisi lingkungan yang sempit dan terbatas. Distorsi lensa yang besar pada lensa fisheye tidak mempengaruhi ketelitian objek secara signifikan apabila dilakukan proses kalibrasi kamera.
\end{abstract}

Kata Kunci: Pemodelan3D, Fotogrametri Rentang Dekat, Lensa Fisheye, Lensa Normal

\section{ABSTRACT}

In 3D modeling, one of the commonly used methods is close-range photogrammetry (CRP). In general, the CRP method uses a normal lens since its distortion is relatively small. Fisheye lens have larger angle of view than normal lens, so they can reduce the number of photos, but have significant distortions that can affect the accuracy of the resulting 3D model. This study aims to test the geometric accuracy between a normal lens and a fisheye lens. This research was conducted in the Ratu Boko Temple area because of accessible area and temple's surface has detail structures. The data used are photos of temple objects, 10 GCP points, and 10 ICP points. The results of $3 D$ models of normal lens and fisheye lens can visualize objects well from the level of detail of the resulting structure. The geometric test was carried out by comparing the distance in the two models with the distance in the field and the ICP size on the two models with the acquired ICP size using a reflectorless total station. Both tests use the t-test with a 95\% confidence level. The results shows that the 3D model of the fisheye lens is the same as the accuracy of the 3D model of the normal lens. Fisheye lens can replace normal lens for 3D modeling in tight and limited environmental conditions. The significant lens distortion on the fisheye lens does not significantly affect the accuracy of the object when the camera calibration process is carried out.

Keywords: Three-dimensional modeling, close range photogrammetry, fisheye lens, normal lens.

(C) Author(s) 2021. This is an open access article under the Creative Commons Attribution-ShareAlike 4.0 International License (CC BY-SA 4.0). 


\section{Pendahuluan}

Pemodelan 3 dimensi (3D) pada saat ini sudah banyak digunakan pada objek-objek buatan manusia seperti warisan budaya, industri, animasi, dll. Seiring berkembangnya teknologi di bidang pemetaan, pemodelan 3D menjadi salah satu opsi yang digunakan dalam bidang perencanaan, konstruksi, ataupun manajemen aset. Pemodelan 3D digunakan untuk mengatasi aspek ketinggian (z) yang tidak dapat disajikan oleh bidang 2 dimensi (2D) pada objek yang cukup rumit dan tidak cukup saat disajikan dalam bidang 2D saja (Wahab, 2009). Terdapat beberapa metode dalam pemodelan 3D, tergantung dengan alat yang digunakan dimana metode tersebut memiliki kekurangan dan kelebihan masingmasing. Salah satu metode untuk pemodelan 3D yang saat ini mulai banyak digunakan adalah fotogrametri rentang dekat (close range photogrammetry).

Fotogrametri rentang dekat merupakan salah satu cabang ilmu dari fotogrametri. Dalam pendokumentasian model 3D, seringkali dilakukan menggunakan Teknik CRP maupun aerial photogrammetry. Hal yang membedakan antara kedua teknik tersebut adalah teknik CRP digunakan untuk objek yang dipotret pada saat posisi kamera dekat dengan objek atau kurang dari 100 meter (Atkinson, 1996). Metode ini akan menghasilkan model 3D yang sesuai kenyataan secara radiometrik dan geometrik dan dapat digunakan untuk dokumentasi (Cowley, 2011). Fotogrametri rentang dekat bisa digunakan untuk memonitoring deformasi dari bangunan, jembatan, dan juga dapat digunakan untuk memodelkan 3D cagar budaya secara detail dengan keadaan sebenarnya (Yastikli \& Emem, 2003).

Pada umumnya, kegiatan CRP ini menggunakan kamera non-metrik karena tipe kamera ini memiliki banyak tipe dan harga yang terjangkau. Kamera non-metrik yang seringkali digunakan adalah Digital Single Lens Reflex (DSLR). Menurut Harintaka (2012) kamera non metrik memiliki kelebihan karena biaya operasional survei yang jauh lebih rendah dibandingkan dengan menggunakan kamera metrik, peralatan kamera yang banyak jenisnya dan mudah diperoleh, serta data yang lebih cepat up to date dibandingkan dengan pemetaan menggunakan citra satelit dan pemetaan secara terestris. Kamera tipe ini seringkali dipasangkan dengan lensa normal. Jenis lensa normal memiliki distorsi yang cukup kecil namun memiliki sudut pandang yang tidak terlalu luas.

Pada sisi lain tersedia lensa fisheye. Lens ini memiliki sudut pandang yang lebih lebar sehingga dapat menghasilkan cakupan yang lebih luas dan dapat menghasilkan daerah pertampalan yang lebih luas terutama untuk pemotretan di ruang yang sempit. Namun demikian lensa fisheye memiliki distorsi yang lebih besar sehingga perlu dilakukan kalibrasi kamera agar dapat memberikan hasil pemotretan yang memiliki kualitas geometri yang baik. (Jonathan dkk,, 2007)

Penelitian yang dilakukan oleh Cattaneo dkk., (2015) dengan melakukan kalibrasi terhadap kamera CCTV yang memiliki lensa fisheye dengan menguji model yang mengabaikan aspek kalibrasi dengan objek yang menggunakan aspek kalibrasi menghasilkan perbedaan yang cukup signifikan. Pada model yang mengabaikan aspek kalibrasi memiliki nilai kesalahan sebesar 43$103 \mathrm{~mm}$ sedangkan pada model yang menggunakan aspek kalibrasi memiliki nilai kesalahan sebesar 0,36-1,83mm.

Salam (2016) melakukan penelitian dengan memodelkan Candi Brahu di Mojokerto menggunakan kamera Digital Single Lens Reflex (DSLR) dan Digital Single Lens Mirrorless (DSLM) dengan Teknik CRP. Kedua lensa tersebut menggunakan jenis lensa normal. Kedua lensa tersebut dilakukan proses kalibrasi yang sama yaitu testfield calibration. Hasil model 3D pada kamera DSLR memiliki ketelitian yang lebih baik dengan nilai RMSE 3,650 cm, sedangkan pada kamera DSLM menghasilkan nilai RMSE sebesar 3,803 cm. Jumlah ICP yang diterima berdasarkan uji $t$ pada kamera DSLR sebesar 70\% sedangkan pada kamera DSLM sebesar $66,67 \%$

Putra (2016) menguji ketelitian pemodelan 3D menggunakan terrestrial laser scanner (TLS) dengan kamera non-metrik dengan studi kasus Candi Singosari di Malang. Pada kamera-non metrik dilakukan test-field calibration untuk meningkatkan ketelitian model. Hasil model 3D pada kamera non-metrik menghasilkan 91\% point clouds yang lebih banyak dibandingkan dengan model hasil TLS. Jumlah ICP yang diterima berdasarkan uji-t pada TLS sebesar $86 \%$ sedangkan pada kamera nonmetrik sebesar $83 \%$.

Barazzetti dkk., (2017) melakukan penelitian tentang pemodelan 3D menggunakan lensa fisheye, dimana lensa fisheye menjadi efektif apabila digunakan untuk pemodelan 3D pada ruang yang sempit sehingga berkas sudut pandang menjadi lebih luas dan dapat membuat keperluan jumlah foto yang digunakan menjadi lebih sedikit. Namun lens ini memiliki kelemahan yaitu efek distorsinya yang besar serta perlu dilakukannya kalibrasi yang optimal untuk mendapatkan hasil model 3D yang baik.

Evaluasi terhadap model stereo pemotretan dengan lensa fisheye juga dilakukan oleh Ohashi dkk (2016) dengan membandingkan hasil pengukuran jarak. Model pendekatan yang dilakukan adalah menggunakan equirectangular images. Hasil yang diperoleh menunjukkan bahwa pendekatan equirectangular images memberikan hasil yang lebih baik dari pada pendekatan perspektif. Disamping itu diperoleh simpangan jarak sekitar $14 \%$.

Pada ruang yang sempit, lensa fisheye dapat memberikan pertampalan yang lebih baik akibat sudut pandang yang luas. Hal ini akan mengurangi keperluan foto dalam tahapan pemodelan. Namun, lensa fisheye memiliki distorsi yang lebih besar dibandingkan lensa normal yang akan berpengaruh terhadap ketelitian model yang dihasilkan sehingga diperlukan metode kalibrasi yang baik. Oleh karena itu, paper ini bertujuan untuk membandingkan kualitas model 3D secara visual yang dihasilkan dari lensa normal dan lensa fisheye dan mendefinisikan serta menghitung nilai ketelitian geometrik model 3D yang dihasilkan antara lensa normal dan lensa fisheye. Paper ini merupakan salah satu bagian dari skripsi yang dilakukan oleh Adi (2021) 


\section{Data dan Metodologi}

Kegiatan pemodelan 3D dilakukan menggunakan 4 titik kontrol yang akan digunakan untuk menentukan 10 titik (ICP) dan 10 titik Independent Check Point (ICP). Kegiatan kalibrasi dilakukan dengan memotret papan checkerboard serta diolah menggunakan software Agisoft Metashape Professional.

\subsection{Data dan Lokasi.}

Pelaksanaan kegiatan ini dilakukan di Kawasan Candi Ratu Boko yang terletak di Dukuh Dawung, Desa Bokoharjo dan Dukuh Sumberwatu, Desa Sambirejo, Kecamatan Prambanan, Kabupaten Sleman, Daerah Istimewa Yogyakarta. Objek Candi Ratu Boko dipilih sebagai model penelitian karena candi tersebut merupakan salah satu peninggalan sejarah yang memiliki nilai budaya di Provinsi Daerah Istimewa Yogyakarta.

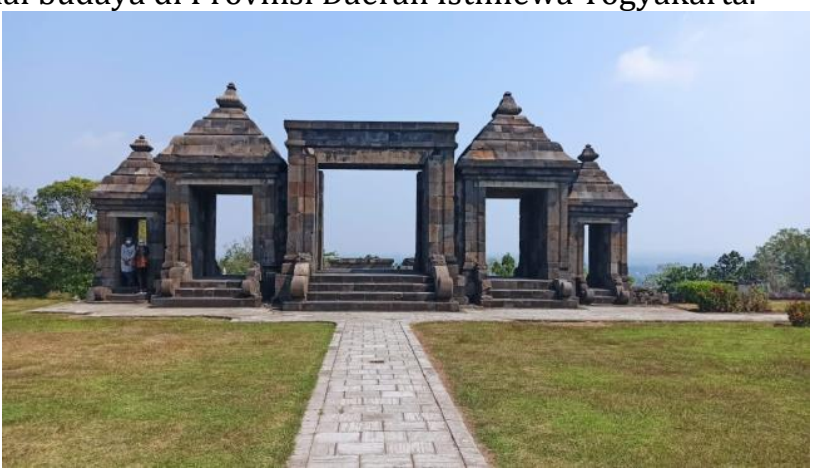

Gambar 1 Objek Penelitian
Objek penelitian ditunjukkan pada Gambar 1. Peralatan yang digunakan dalam penelitian ini adalah total station reflectorless, receiver GNSS Geodetik, kamera non-metrik (DSLR), lensa normal, lensa fisheye, meteran baja, software Agisoft Metashape Professional, JPS2RIN, dan Microsoft Office. Bahan penelitian yang digunakan adalah data hasil pemotretan objek candi menggunakan lensa normal dan lensa fisheye. Data 4 titik kontrol yang digunakan untuk mengakuisisi titik GCP serta ICP. Serta pengukuran jarak terhadap beberapa sampel bagian candi. Data nilai IOP hasil kalibrasi kamera menggunakan lensa normal dan lensa fisheye untuk proses pemodelan 3D pada software.

\subsection{Metodologi}

Konsep akuisisi data dalam penelitian ini adalah menggunakan metode close range photogrammetry dengan rencana nilai GSD 2,4mm. Akuisisi 4 titik kontrol menggunakan metode GNSS relatif statik yang akan digunakan untuk menentukan 10 titik GCP dan 10 titik ICP yang diakuisisi menggunakan total station reflectorless dengan menggunakan metode pengikatan kemuka.

Sebelum dilakukan pemotretan objek, dilakukan kalibrasi kamera menggunakan metode test-field calibration dengan memotret bidang checkerboard dari beberapa sisi. Proses kalibrasi kamera menggunakan fitur calibrate lens yang terdapat pada software Agisoft Metashape Professional. Adapun diagram alir penelitian ini, dapat dilihat pada Gambar 2.

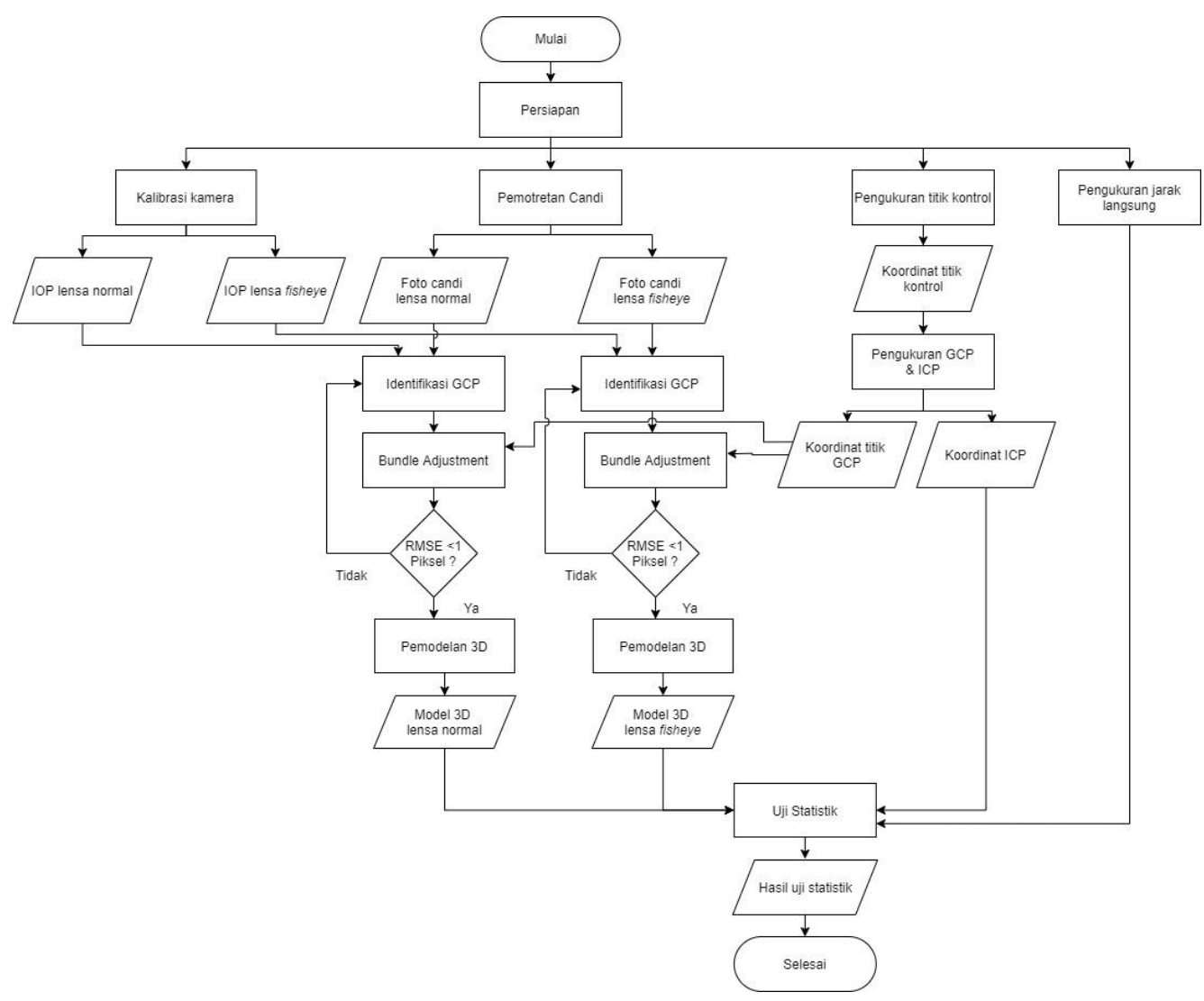

Gambar 2 Diagram Alir Penelitian 


\subsection{Kalibrasi Kamera}

Kamera non-metrik tidak memiliki lensa yang sempurna, dimana selalu terdapat distorsi didalamnya. Maka dari itu, perlu dilakukan proses kalibrasi kamera untuk membuat model 3D yang dihasilkan menjadi akurat. Proses kalibrasi kamera dilakukan untuk mendapatkan nilai Internal Orientation Parameter (IOP) yang terdiri dari principal distance (c), principal point (Xo,Yo), distorsi radial (K1, K2, K3), distorsi tangensial (P1, P2), dan affinity deformation (B1, B2) (Fraser, 1997). Menurut Luhmann et al., (2014) terdapat beberapa metode kalibrasi yang dapat digunakan dan dibedakan berdasarkan waktu dan objek kalibrasi. Beberapa metode kalibrasi tersebut adalah sebagai berikut :

1. Laboratory calibration, merupakan Teknik yang seringkali digunakan pada kamera metrik. Nilai IOP didapatkan dengan goniometer, collimators, atau instrument optical lainnya.

2. Test-field calibration, merupakan teknik yang dilakukan dengan merekam bidang target yang terdiri dari titik-titik objek dengan koordinat atau jarak yang sudah diketahui.

3. Plumb-line calibration, dilakukan mirip dengan proses test-field calibration namun menggunakan beberapa garis lurus misalnya terbuat dari kawat yang digantung secara vertikal.

4. On the job calibration, merupakan teknik kalibrasi yang mirip dengan test-field calibration namun menggunakan objek sebenarnya yang akan diukur.

5. Self-calibration, merupakan proses lanjutan teknik testfield calibration dan on the job calibration.

Metode kalibrasi kamera yang digunakan pada penelitian ini adalah test-field calibration. Pemotretan foto untuk kalibrasi kamera dilakukan menggunakan kamera DSLR dilengkapi dengan lensa normal dan lensa fisheye. Papan kalibrasi yang digunakan adalah checkerboard yang sudah tersedia pada software Agisoft Metashape Professional. Papan kalibrasi yang digunakan ditunjukkan pada Gambar 3. Pemotretan dilakukan dari berbagai sudut pandang hingga mendapatkan nilai RMSE $<1$ piksel.

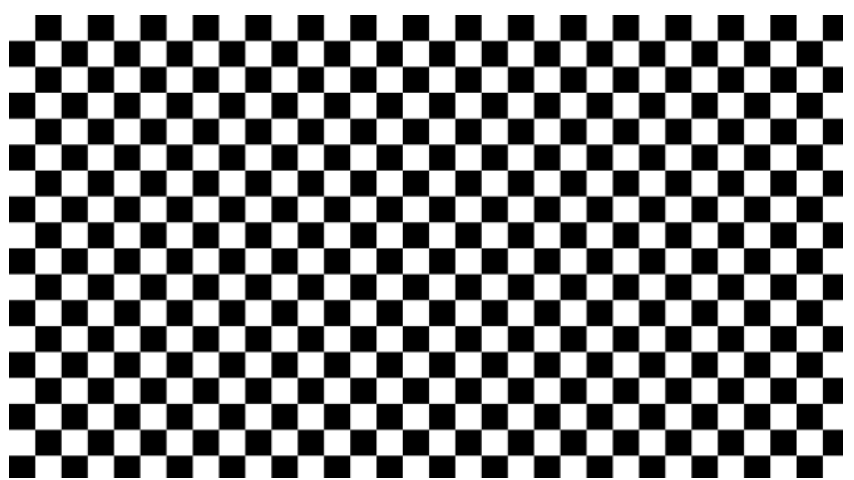

Gambar 3 Papan kalibrasi

\subsection{Akuisisi titik kontrol}

Akuisisi titik kontrol menggunakan pengamatan GNSS metode relatif statik. Penentuan menggunakan metode ini adalah adanya titik ikat yang memiliki ketelitian yang lebih tinggi (Kaplan \& Hegarty, 2017). Pengukuran dilakukan selama 40 menit pada setiap titik kontrol. Pengolahan data dilakukan menggunakan layanan post processing pada https:/inacors.big.go.id/sbc. Hasil data RAW dikonversi terlebih dahulu menjadi RINEX kemudian layanan Ina-CORS akan melakukan pengolahan data secara otomatis dan mengaitkan dengan titik CORS terdekat. Layanan ini memfasilitasi untuk melakukan pengolahan data GNSS statik secara otomatis dan hasilnya dapat langsung digunakan. Saat ini layanan post processing hanya terdapat di wilayah Pulau Jawa. Persebaran titik kontrol ditunjukkan pada Gambar 4.

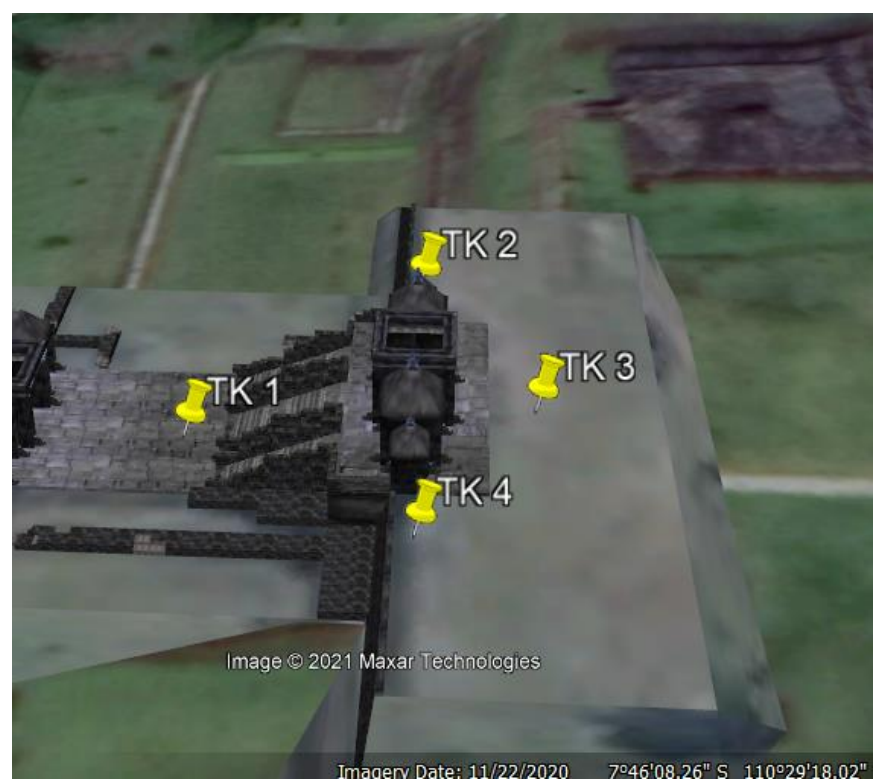

Gambar 4 Persebaran titik kontrol (Sumber : Google Earth, 2021)

\subsection{Pemotretan objek}

Pemotretan dilakukan menggunakan metode close range photogrammetry menggunakan lensa normal dan lensa fisheye. Skala foto yang diharapkan adalah 1:550 sehingga untuk lensa fisheye perlu dilakukan pengaturan focal length $8 \mathrm{~mm}$ dengan jarak 4,4 $\mathrm{m}$ sedangkan lensa normal dilakukan pengaturan focal length sebesar $18 \mathrm{~mm}$ dan jarak $10 \mathrm{~m}$. Pemotretan dilakukan pada pukul 13.0014.00 WIB untuk mendapatkan pencahayaan yang optimal. 2.5. Pengukuran GCP dan ICP

Pengukuran GCP dan ICP dilakukan menggunakan total station reflectorless. Koordinat $\mathrm{x}, \mathrm{y}$, dan $\mathrm{z}$ didapatkan menggunakan pengikatan kemuka dengan acuan titik kontrol yang sudah diakuisisi sebelumnya. Persebaran titik GCP dan ICP didesain menyebar meliputi seluruh bagian candi. Pemilihan titik GCP dan ICP berada pada sudut-sudut bangunan candi dan beberapa batu yang mudah diidentifikasi yang bertujuan untuk mempermudah proses interpretasi titik pada saat pengolahan data di software. Dalam pengambilan data GCP dan ICP juga harus memperhatikan pengaturan alat berupa prisma standar sebagai titik backsight. Hasil akuisisi data GCP dan ICP 
dapat diunduh dari total station reflectorless dalam bentuk koordinat maupun RAW data yang berformat *txt.

\subsection{Pemodelan 3D}

Pengolahan model 3D pada software Agisoft Metashape Professional terdiri dari beberapa tahapan seperti align photo, pembentukan dense cloud, pembentukan mesh dan tekstur. (Agisoft, 2019). Menurut Patias (2004) terdapat beberapa keuntungan dengan memanfaatkan pemodelan 3D untuk mendokumentasikan suatu objek penting. Beberapa keuntungan yang dimaksud adalah sebagai berikut :

1. Memiliki kualitas resolusi yang baik, dapat membantu proses interpretasi pengguna serta dapat menyediakan informasi secara lebih lengkap serta menarik.

2. Sarana visualisasi yang dapat dikaitkan melalui internet sebagai online database.

3. Sebagai inventarisasi secara digital untuk keperluan edukasi, penelitian, dan hiburan.

Pengolahan data foto dilakukan dengan pembuatan stereo foto yang meliputi alignment photo, proses gradual selection, pembuatan dense cloud, serta mesh dan texture. Gradual selection bertujuan untuk menghilangkan point cloud yang memiliki nilai error yang tinggi sehingga dapat memperbaiki ketelitian model 3D. Tahapan dense cloud akan memvisualisasikan model dari tie point yang dihasilkan dari proses align photo dengan lebih rapat. Selain itu, dense cloud dapat memvisualisasikan unsur warna dari model 3D yang diproses. Tahapan mesh terjadi pembuatan bidang berdasarkan dense cloud untuk merekonstruksi model 3D yang lebih rapat. Selain tu, tahapan ini juga akan memperbaiki lubang-lubang yang terdapat pada model akibat adanya bagian foto yang kurang bertampalan atau perbedaan pencahayaan pada saat proses pemotretan. Prinsip dari pembentukan mesh ini adalah dengan interpolasi pendekatan model data Triangulated Irregular Networks (TIN). Pada tahapan texture, model 3D akan memiliki texture dan warna yang mirip dengan objek aslinya.

\subsection{Analisa model 3D}

Proses analisis dilakukan menggunakan dua metode, yaitu metode kualitatif dan metode kuantitatif. Analisa kualitatif dilakukan berdasarkan banyaknya feature yang terbentuk dan interpretasi visual dari model 3D yang dihasilkan. Analisa kuantitatif dilakukan dengan menghitung nilai ketelitian jarak dan koordinat ICP pada model berdasarkan data hasil pengukuran di lapangan. Uji statistic digunakan untuk mengetahui ketelitian dari perbedaan nilai ukuran/sampel dengan nilai yang dianggap benar/populasi. Uji ketelitian jarak dan koordinat dilakukan menggunakan uji-t dengan derajat kepercayaan 95\%.

\section{Hasil dan Pembahasan}

\subsection{Titik Kontrol Hasil Pengamatan GNSS}

Pengukuran dilakukan menggunakan metode statik yang menghasilkan empat titik kontrol di sekitar objek candi.
Titik satu, dua, tiga, dan empat masing-masing berada di sebelah barat, utara, timur, dan selatan objek candi. Persebaran empat titik kontrol tersebut sudah dapat melingkupi keseluruhan objek candi untuk pengukuran titik GCP dan ICP. Sistem koordinat yang digunakan adalah Universal Transverse Mercator (UTM) zone 49s dengan sistem tinggi geometrik. Titik kontrol ini akan digunakan sebagai acuan berdirinya alat total station reflectorless untuk membidik titik GCP dan ICP yang terletak di objek candi.

Tabel 1 Titik Kontrol

\begin{tabular}{cccc}
\hline $\begin{array}{c}\text { Titik } \\
\text { kontrol }\end{array}$ & Easting (m) & Northing (m) & Height (m) \\
\hline 1 & 443584,530 & 9141162,517 & 225,756 \\
2 & 443604,502 & 9141179,229 & 229,156 \\
3 & 443615,338 & 9141161,226 & 229,219 \\
4 & 443603,347 & 9141145,684 & 229,058 \\
\hline
\end{tabular}

\subsection{Titik GCP dan ICP}

Penentuan titik GCP dan ICP menggunakan metode tachymetri dimana jarak ditentukan dengan cara optis dan beda tinggi ditentukan berdasarkan sudut vertikal dan arah ditentukan dengan bacaan horizontal (Basuki, 2006). Titik GCP dan ICP tersebut akan digunakan sebagai titik acuan saat pengolahan di software Agisoft Metashape Professional. Terdapat 10 titik GCP yang digunakan sebagai titik kontrol dalam proses georeference dan 10 titik ICP yang digunakan untuk mengetahui nilai ketelitian dari model 3D yang dihasilkan.

Tabel 2 Koordinat titik GCP

\begin{tabular}{cccc}
\hline Titik & Easting (m) & Northing (m) & Height (m) \\
\hline GCP 1 & 443606,04 & 9141168,32 & 233,52 \\
GCP 2 & 443605,29 & 9141179,54 & 232,41 \\
GCP 3 & 443606,02 & 9141159,19 & 234,61 \\
GCP 4 & 443604,34 & 9141153,05 & 232,40 \\
GCP 5 & 443602,89 & 9141179,66 & 232,55 \\
GCP 6 & 443598,58 & 9141170,85 & 229,41 \\
GCP 7 & 443601,18 & 9141164,65 & 234,73 \\
GCP 8 & 443601,86 & 9141153,12 & 232,49 \\
GCP 9 & 443589,46 & 9141164,06 & 227,97 \\
GCP 10 & 443597,41 & 9141153,07 & 228,39 \\
\hline
\end{tabular}

Tabel 3 Koordinat titik ICP

\begin{tabular}{cccc}
\hline Titik & Easting (m) & Northing (m) & $\begin{array}{c}\text { Height } \\
\text { (m) }\end{array}$ \\
\hline ICP 1 & 443604,33 & 9141170,42 & 230,95 \\
ICP 2 & 443593,53 & 9141164,11 & 229,99 \\
ICP 3 & 443591,35 & 9141160,48 & 228,39 \\
ICP 4 & 443595,30 & 9141159,00 & 229,98 \\
ICP 5 & 443607,87 & 9141164,03 & 229,30 \\
ICP 6 & 443607,18 & 9141167,69 & 229,37 \\
ICP 7 & 443602,98 & 9141170,56 & 232,73 \\
ICP 8 & 443601,37 & 9141164,54 & 232,81 \\
ICP 9 & 443590,80 & 9141158,68 & 227,70 \\
ICP 10 & 443590,83 & 9141156,36 & 227,71 \\
\hline
\end{tabular}




\subsection{Kalibrasi kamera}

Kalibrasi kamera dilakukan menggunakan lensa normal dan lensa fisheye menggunakan metode test-field calibration. Kalibrasi dilakukan dengan memotret checkerboard yang sudah tersedia pada software Agisoft Metashape Professional dengan mengatur nilai focal length pada masing-masing lensa sama dengan saat memotret objek candi dimana nilai focal length lensa normal dan fisheye masing-masing adalah $18 \mathrm{~mm}$ dan $8 \mathrm{~mm}$. Parameter kalibrasi yang digunakan pada kedua lensa yaitu principal distance (c), principal point (Xo, Yo), distorsi lensa (K1, K2, K3, P1, dan P2), serta distorsi akibat penskalaan serta posisi ortogonal sumbu $\mathrm{x}$ dan y (B1 dan B2). Lensa normal menghasilkan nilai overall reprojection error sebesar 0.354615 sedangkan pada lensa fisheye sebesar 0.477959 . Nilai parameter IOP yang didapatkan pada kedua lensa dapat dilihat pada Tabel 4, dan Tabel 5.

Tabel 4 Nilai IOP lensa normal

\begin{tabular}{ccc}
\hline $\begin{array}{c}\text { Camera } \\
\text { Variable }\end{array}$ & Nilai Parameter & $\begin{array}{c}\text { Standar } \\
\text { Deviasi }\end{array}$ \\
\hline$c$ & $18,865(\mathrm{~mm})$ & $0,032(\mathrm{~mm})$ \\
Xo & $-0,235(\mathrm{~mm})$ & $0,008(\mathrm{~mm})$ \\
Yo & $-0,071(\mathrm{~mm})$ & $0,006(\mathrm{~mm})$ \\
K1 & $5,795 \times 10^{-4}$ & $8,637 \times 10^{-5}$ \\
K2 & $-2,648 \times 10^{-6}$ & $1,589 \times 10^{-5}$ \\
K3 & $8,541 \times 10^{-9}$ & $8,476 \times 10^{-9}$ \\
P1 & $6,356 \times 10^{-9}$ & $9,593 \times 10^{-6}$ \\
P2 & $-1,296 \times 10^{-4}$ & $1,448 \times 10^{-5}$ \\
B1 & $-3,440 \times 10^{-6}$ & $5,425 \times 10^{-7}$ \\
B2 & $5,978 \times 10^{-5}$ & $4,696 \times 10^{-5}$ \\
\hline
\end{tabular}

Tabel 5 Nilai IOP lensa fisheye

\begin{tabular}{ccc}
\hline $\begin{array}{c}\text { Camera } \\
\text { Variable }\end{array}$ & Nilai Parameter & $\begin{array}{c}\text { Standar } \\
\text { Deviasi }\end{array}$ \\
\hline$c$ & $8,558(\mathrm{~mm})$ & $0,014(\mathrm{~mm})$ \\
Xo & $-0,076(\mathrm{~mm})$ & $0,003(\mathrm{~mm})$ \\
Yo & $-0,120(\mathrm{~mm})$ & $0,002(\mathrm{~mm})$ \\
K1 & $2,495 \times 10^{-3}$ & $9,249 \times 10^{-5}$ \\
K2 & $5,353 \times 10^{-5}$ & $2,657 \times 10^{-5}$ \\
K3 & $-2,174 \times 10^{-7}$ & $8,476 \times 10^{-9}$ \\
P1 & $5,456 \times 10^{-5}$ & $9,593 \times 10^{-6}$ \\
P2 & $-1,046 \times 10^{-4}$ & $1,448 \times 10^{-5}$ \\
B1 & $-5,836 \times 10^{-4}$ & $5,425 \times 10^{-7}$ \\
B2 & $-1,060 \times 10^{-4}$ & $4,696 \times 10^{-5}$ \\
\hline
\end{tabular}

\subsection{Pemodelan 3D}

Proses pemodelan 3D terdiri dari beberapa tahapan yaitu align photo, georeference, dense cloud, mesh, dan texture. Pemodelan dilakukan menggunakan software Agisoft metashape Professional.

Pada tahapan align photo terjadi proses identifikasi terhadap titik-titik yang sama pada beberapa foto yang berbeda. Lensa normal menghasilkan sebanyak 196.808 tie point sedangkan lensa fisheye menghasilkan 69.113 tie point. Perbedaan jumlah titik ini dipengaruhi oleh kecocokan kecocokan feature yang dihasilkan oleh kedua lensa.
Proses georeference dilakukan untuk mentransformasikan koordinat model ke koordinat tanah. Pada tahapan ini digunakan 10 titik GCP sebagai titik kontrol dan 10 titik ICP untuk mengevaluasi ketelitian model 3D yang dihasilkan. Hasil georeference pada lensa normal dan fisheye dapat dilihat pada Tabel 6.

Tabel 6 Hasil tahapan georeference

\begin{tabular}{ccc}
\hline Camera & \multicolumn{2}{c}{ Eror (m) } \\
\cline { 2 - 3 } Variable & Lensa normal & Lensa fisheye \\
\hline GCP & 0,0021 & 0,0019 \\
ICP & 0,0394 & 0,0462 \\
\hline
\end{tabular}

Tahapan dense cloud akan merapatkan sparse point cloud yang dihasilkan saat prose align photo. Pembentukan dense cloud pada kedua lensa menggunakan parameter yang sama. Lensa normal menghasilkan point cloud sebanyak 4.652.166 sedangkan pada lensa fisheye menghasilkan point cloud sebanyak 4.452.345. Perbedaan jumlah titik tersebut dipengaruhi oleh kecocokan feature yang dihasilkan saat proses.

Hasil dari tahapan dense cloud akan dibuat menjadi sebuah permukaan yang solid dalam tahapan mesh. Model 3D lensa normal menghasilkan faces 291.534 dan vertices 148.299, sedangkan pada lensa fisheye menghasilkan 279.269 faces dan 142.820 vertices.

Hasil dari tahapan texture adalah model 3D sudah memiliki bentuk yang solid serta memiliki warna dan tekstur yang menyerupai model aslinya, Meskipun pembentukan texture telah dilakukan, namun masih terdapat beberapa lubang pada kedua model, yaitu celah kecil diantara kedua tangga. Hal tersebut dikarenakan jarak pemotretan dan kurang terekamnya bagian objek tersebut pada kamera.

\subsection{Analisa model 3D}

Analisa yang dilakukan pada kedua model adalah secara kualitatif dan kuantitatif. Analisa kualitatif dilakukan berdasarkan hasil visualisasi dari kedua model dan Analisa kuantitatif dilakukan berdasarkan uji ketelitian jarak dan uji ketelitian koordinat.

Hasil model 3D yang dihasilkan pada oleh kedua lensa secara struktur sudah menyerupai objek sebenarnya dari kenampakan permukaan hingga ketegasan pada beberapa objek datar seperti tangga dan tembok. Model 3D pada kedua lensa juga sudah memiliki tingkat kedetailan yang baik, dapat dilihat pada sudut-sudut dan lekukan pada objek candi. Terdapat beberapa daerah yang tidak termodelkan dengan baik yaitu pada bagian atas tangga, lantai pada bagian dalam candi serta atap candi. Hal ini diakibatkan oleh perbedaan ketinggian yang cukup signifikan pada sekitar objek candi sehingga tidak bisa merekam objek tersebut, serta penggunaan alat yang tidak bisa memotret dari sudut pandang objek yang cukup tinggi sehingga tidak bisa menjangkau beberapa objek tertentu. Beberapa sampel model 3D lensa normal dan lensa fisheye dapat dilihat pada Gambar 5. 

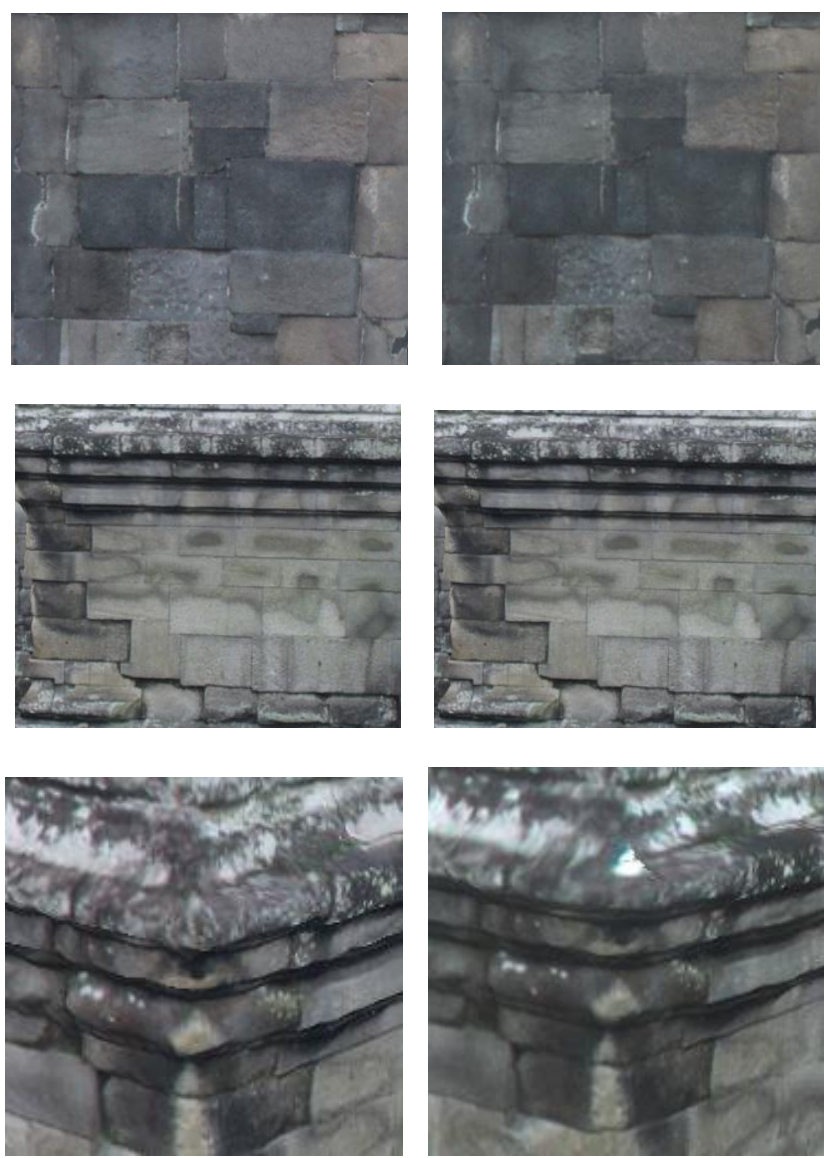

Gambar 5 Sampel model 3D (kiri) lensa normal (kanan lensa fisheye

Tabel 7 Hasil uji ketelitian jarak

\begin{tabular}{ccc}
\hline & \multicolumn{2}{c}{$\begin{array}{c}\text { Selisih jarak di lapangan dengan model } \\
\text { 3D yang dihasilkan (m) }\end{array}$} \\
\cline { 2 - 3 } Objek & Lensa normal & Lensa fisheye \\
\hline Jarak 1 & 0,005 & 0,003 \\
Jarak 2 & 0,005 & 0,006 \\
Jarak 3 & 0,049 & 0,052 \\
Jarak 4 & 0,006 & 0,009 \\
Jarak 5 & 0,013 & 0,012 \\
Jarak 6 & 0,007 & 0,010 \\
Jarak 7 & 0,007 & 0,009 \\
Jarak 8 & 0,003 & 0,007 \\
Jarak 9 & 0,008 & 0,017 \\
Jarak 10 & 0,005 & 0,024 \\
Jarak 11 & 0,011 & 0,014 \\
Jarak 12 & 0,027 & 0,040 \\
Jarak 13 & 0,039 & 0,038 \\
Jarak 14 & 0,043 & 0,042 \\
Jarak 15 & 0,014 & 0,008 \\
\hline \multicolumn{3}{c}{ Standar Deviasi } \\
\hline \multicolumn{3}{c}{ T Hitung } \\
\hline
\end{tabular}

Uji ketelitian jarak dilakukan dengan membandingkan ukuran jarak di lapangan dengan jarak pada model. Pengukuran jarak langsung dilakukan menggunakan meteran baja sedangkan pengukuran jarak pada model menggunakan fitur scale bar yang tersedia di software Agisoft metashape Professional. Pengujian menggunakan uji-t dengan tingkat kepercayaan sebesar 95\%. Hasil uji t ditunjukkan pada Tabel 7.

Berdasarkan Tabel 7 dapat dilihat bahwa nilai t hitung < t tabel sehingga dapat disimpulkan bahwa pernyataan Ho diterima sehingga ketelitian model 3D lensa fisheye sama dengan ketelitian model 3D lensa normal.

Uji ketelitian koordinat dilakukan dengan membandingkan nilai koordinat ICP hasil pengukuran total station reflectorless dengan nilai ICP yang didapatkan dari model 3D yang dihasilkan. Jumlah titik ICP yang digunakan untuk uji adalah 10 titik. Pengujian menggunakan uji-t dengan tingkat kepercayaan sebesar 95\%. Hasil uji- t dapat dilihat pada Tabel 8.

Tabel 8 Hasil uji ketelitian koordinat

\begin{tabular}{cc}
\hline Titik & $\begin{array}{c}\text { Selisih koordinat lensa } \\
\text { normal dengan lensa } \\
\text { fisheye }(\mathbf{m})\end{array}$ \\
\hline ICP 1 & 0,0001 \\
ICP 2 & 0,0077 \\
ICP 3 & 0,0035 \\
ICP 4 & 0,0011 \\
ICP 5 & 0,0087 \\
ICP 6 & 0,0057 \\
ICP 7 & 0,0021 \\
ICP 8 & 0,0020 \\
ICP 9 & 0,0033 \\
ICP 10 & 0,0058 \\
\hline Standar Deviasi & 0,0029 \\
\hline T Hitung & 0,7292 \\
\hline T Tabel & 2,228 \\
\hline
\end{tabular}

Berdasarkan Tabel 8 dapat dilihat bahwa nilai thitung < t tabel sehingga dapat disimpulkan bahwa pernyataan Ho diterima sehingga ketelitian model 3D lensa fisheye sama dengan ketelitian model 3D lensa normal.

\section{Kesimpulan}

Model 3D lensa normal dan lensa fisheye secara umum sudah dapat memvisualisasikan tingkat kedetailan objek dengan baik, dapat dilihat dari tangga dan corak tembok serta mampu memvisualisasikan struktur objek dengan baik yang dapat dilihat dari sudut-sudut dan lekukan pada candi. Rekonstruksi model 3D pada lensa normal menghasilkan feature yang lebih baik daripada lensa fisheye.

Pengujian ketelitian geometrik pada kedua model dilakukan dengan menguji jarak sebenarnya dengan jarak pada kedua model dan titik ICP yang didapatkan menggunakan total station reflectorless dengan kedua model yang dihasilkan. Uji t menggunakan jarak dan koordinat pada kedua model menunjukkan bahwa ketelitian model 3D lensa fisheye sama dengan ketelitian model 3D lensa normal. 


\section{Pernyataan Konflik Kepentingan}

Penulis menyatakan tidak ada konflik kepentingan dalam artikel ini (The authors declare no competing interest).

\section{Referensi}

Adi, N. (2021). Analisis Perbandingan Ketelitian Model 3D Menggunakan Lensa Normal dan Lensa Fisheye. Skripsi. Departemen Teknik Geodesi FT-UGM. Yogyakarta

Agisoft Metashape version 1.5. (2019). Agisoft Metashape User Manual. Agisoft Metashape, September, 160. https://www.agisoft.com/pdf/metashapepro_1_5_en.pdf

Atkinson. (1996). Close Range Photogrametry and Machine Vision. In Close Range Photogrametri. Scotland UK : Whittles Publisher.

Barazzetti, L., Previtali, M., \& Roncoroni, F. (2017). Fisheye lenses for 3D modeling: Evaluations and considerations. International Archives of the Photogrammetry, Remote Sensing and Spatial Information Sciences - ISPRS Archives, 42(2W3), 7984. https://doi.org/10.5194/isprs-archives-XLII-2W3-79-2017

Basuki, S. (2006). Ilmu Ukur Tanah (Edisi Revisi). Gadjah Mada University Press.

Cattaneo, C., Mainetti, G., \& Sala, R. (2015). The importance of camera calibration and distortion correction to obtain measurements with video surveillance systems. In Journal of Physics: Conference Series (Vol. 658, Issue 1). ISPRS Archieve. https://doi.org/10.1088/17426596/658/1/012009

Cowley, D. . (2011). Remote Sensing for Archeological Herritage Management (Vol. 5). EAC Occasional Paper.

Fraser. (1997). Digital camera self-calibration. In Journal of Photogrammetry and Remote Sensing. ISPRS Journal of Photogrammetry and Remote Sensing.

Harintaka. (2012). Pengembangan Pemrosesan Fotogrametri Digital Foto Udara Format Kecil untuk Penyediaan Data Spasial. Universitas Gadjah Mada.

Jonathan C., Youcef M., Laurent E., Philippe M. (2007). A Generic Fisheye camera model for robotic applications. Proceedings of the 2007 IEEE/RSJ International Conference on Intelligent Robots and Systems San Diego. Oct 29-Nov 2 2007.CA, USA,

Kaplan, E. D. \& Hegarty, C. J. (2017). Understanding GPS/GNSS Principles and Applications (3rd Editio). Artech House Boston.

Luhmann, B. T., Robson, S., Kyle, S., \& Jan. (2014). CloseRange Photogrammetry and $3 D$ Imaging 2nd edition. Walter de Gruyter GmbH, Berlin/Boston.

Ohashi A., Tanaka ,Y. Fukuda, Takehito O. D, Kota I. (2016) Fisheye stereo camera using equirectangular images. MECATRONICS - REM June 15-17, 2016

Patias, P. (2004). Overview of applications of close-range photogrammetry and vision techniques in architecture and archaeology. In: McGlone C (ed) Manual of Photogrammetry. Maryland: American Society of Photogrammetry.

Putra, A. R. (2016). Pemodelan 3D Dengan Menggunakan Metode Sturcture From Motion dan Terrestrial Laser Scanning ( Studi Kasus : Candi Singosari , Malang ) 3D Modeling Using Structure From Motion and Terrestrial Laser Scanning. Skripsi. Jurusan Teknik Geomatika Fakultas Teknik Sipil dan Perencanaan, Institut Teknologi Sepuluh November.

Salam, M. S. (2016). Pemanfaatan Fotogrametri Rentang Dekat untuk Pemodelan 3D Cagar Budaya Menggunakan Kamera Non-metrik (Studi Kasus: Candi Brahu, Mojokerto) (Issue December). Skripsi. Jurusan Teknik Geomatika, Departemen Teknik Sipil dan Perencanaan, Institut Teknologi Sepuluh November.

Wahab, A. G. (2009). Analisis Geometri Data Objek Tiga Dimensi Menggunakan Fotogrametri Rentang Dekat, Terestrial Laser Scanning, dan Electronic Total Station (ETS). In Fotogrametri Rentang Dekat. Program Studi Teknik Geodesi dan Geomatika, Institut Teknologi Bandung.

Yastikli, N., Emem, O. (2003). 3D Model Generation and Visualization of Cultural Heritage. In Remote Sensing. Istanbul:Yildiz Technical University, Civil Engineering Faculty, Division of Photogrammetry and Remote Sensing. 